\title{
Not more but different: A comment on the transitions research agenda
}

\author{
Hopkins D, Kester J, Meelen T and Schwanen T
}

\section{Introduction}

The comprehensive agenda for sustainability transitions research (STR) presented by Köhler et al. (2019) demonstrates that the field has grown rapidly, diversified and matured. Given such flourishing, what is there left to do? A key challenge, we propose, is to make more space for doing transitions theory - and by implication, methodology, epistemology and ontology differently.

There is substantial theoretical diversity in the field owing to the plural theoretical origins of foundational core STR frameworks such as the Multi-Level Perspective, Technological Innovation Systems, Strategic Niche Management and Transition Management (Markard et al, 2012). A comparison of Köhler et al.'s research agenda with a recent review by Zolfagharian et al. (2019) shows the former to be less plural in its description of the field in theoretical terms than it could have been. Calls for theoretical - and methodological and philosophical - pluralism in STR are not new (Stirling, 2011) yet we feel that it is important to reiterate this now, given that Köhler et al.'s research agenda will likely be an important reference in future for early-career and established scholars alike.

While theoretical diversity exists and appears to be increasing in STR, it is also true that attempts at theoretical diversification often retain many assumptions of the core transition frameworks (e.g. continued supremacy of capitalist systems - Feola, 2019). Similarly, such attempts frequently mix elements from alternative frameworks or traditions with/into core frameworks, or continue to use concepts such as 'niche' and 'regime' (e.g. Rauschmayer et al., 2015; Ford et al., 2017; van Welie et al., 2019). These tendencies are productive and useful on one level as they allow STR to go on in puzzle-solving, normal science mode (Kuhn, 1962). On another level, they mean that the full potential and diversity of insights those alternative frameworks might offer remains largely untapped. This is why we propose starting STR from within alternative theoretical traditions and working through transition processes with these traditions on their own terms.

This approach is certainly not without risks. We offer a preliminary effort to elaborate these, along with concomitant opportunities in Table 1. While further work is needed to develop the ideas presented in Table 1, we believe that there are significant benefits from what we have in mind, especially if 'contact zones' are created and institutionalised. These are sites (projects, events, fora, publications) where protagonists of different frameworks and traditions meet, listen to deliberate with and learn from each other in the context of uneven power relations (see Schwanen, 2018).

Table 1: Selected risks and opportunities of more radical theoretical pluralism in STR

\begin{tabular}{|c|c|c|}
\hline Dimension & Risks & Opportunities \\
\hline Internal relations & $\begin{array}{l}\text { Fragmentation and potential } \\
\text { loss of: } \\
\text { - } \quad \text { conceptual Esperanto } \\
\text { - } \quad \text { shared worldviews and } \\
\text { problematisations } \\
\text { - } \quad \text { sense of STR community }\end{array}$ & $\begin{array}{l}\text { Potential for: } \\
\text { - } \text { novel, more diverse } \\
\text { conceptual/substantive insights } \\
\text { - greater reflexivity and internal } \\
\text { debate regarding black-boxed } \\
\text { assumptions and power relations }\end{array}$ \\
\hline External relations & $\begin{array}{l}\text { Loss of recognisability and } \\
\text { identity within/beyond } \\
\text { academia }\end{array}$ & $\begin{array}{l}\text { Potential for: } \\
\text { - } \quad \text { Even greater entry of } \\
\text { scholars/scientists with diverse }\end{array}$ \\
\hline
\end{tabular}




\begin{tabular}{|l|l|l|}
\hline & $\begin{array}{l}\text { Slowing down of formation of } \\
\text { STR as externally validated } \\
\text { discipline }\end{array}$ & $\begin{array}{l}\text { training/backgrounds/ } \\
\text { geographies } \\
\text { Different/complementary } \\
\text { recommendations for non- } \\
\text { academic stakeholders }\end{array}$ \\
\hline Conceptualisation & $\begin{array}{l}\text { Potential loss of explicit } \\
\text { multidimensionality in how } \\
\text { transitions are conceptualised }\end{array}$ & $\begin{array}{l}\text { Possibilities to rethink multiplicity } \\
\text { of/in transitions, the categorisation } \\
\text { of dimensions, and relations } \\
\text { between them }\end{array}$ \\
\hline Questions & $\begin{array}{l}\text { Return to 'same old' questions } \\
\text { about e.g. capitalism, power, } \\
\text { equity, and thereby offering } \\
\text { predictable answers }\end{array}$ & $\begin{array}{l}\text { Engaging with questions of } \\
\text { enduring/renewed relevance beyond } \\
\text { academia (e.g. Guardian Polluters } \\
\text { Series [The Guardian, 2019]) over } \\
\text { issues including: } \\
\text { Disenfranchisement linked to } \\
\text { innovation and pro-transition } \\
\text { policies }\end{array}$ \\
& $\begin{array}{l}\text { Distribution of responsibilities } \\
\text { for, and capacities to enact, } \\
\text { change }\end{array}$ \\
\hline
\end{tabular}

Below we begin to introduce some of the possibilities and insights that emerge from fully grounding STR in different theoretical traditions. The two traditions we use as initial examples have seen at least some engagement in STR but in neither case do we believe have their potentials been exhausted. The selection of traditions is fairly arbitrary; experimentation with others is warranted.

\section{Foucauldian tradition}

STR has absorbed various elements of Foucauldian thinking, for instance about power, discourse and discursive practices (Smith and Raven, 2012; Avelino et al., 2016).

Nonetheless, the full potential of Foucault's original and more recent work on power, knowledge, governmentality and subjectivities for STR remains to be harnessed. Foucault's notion of the dispositif - an arrangement of discourses, procedures, institutions, habits, moralities and materialities that generates and strategically responds to problems in a given context (Bussolini, 2010) - provides an alternative to the well-known innovation system or socio-technical regime. The former is arguably more multiple, emergent, performative and full of tensions and contradictions, reflecting the idea that orders are heterogenous and need to be continuously (re)enacted. It opens up a relational perspective on immanent transitions, continuously emerging from within rather than driven by external(ised) micro- or macrolevel developments as might be reflected by STR frameworks.

Foucauldian thinking also problematises the notions of actor and actor orientation without dispensing with the human actor altogether. It shifts attention to transformations in how changing power relations involving discourses, knowledges and techniques (re)constitute (human) subjects in novel ways. This is of direct significance to questions of how transitions are enacted and how responsibilities and capabilities for change are (supposed to be) distributed. Finally, thinking about governmentality places risks and threats and how to govern them at the centre of attention: What is considered risky, when, where and by whom/what? Which calculative, surveillance and insurance practices and techniques are used to pre-empt and mitigate risks and threats? Addressing these and related questions has the potential to offer novel insights into how innovation and transition processes (might) evolve. 


\section{Post/decolonial traditions}

The STRN research agenda highlights the geographical diversification of transition theories and approaches as a measure of its success. Core theoretical frameworks have been applied productively beyond the 'West' and to varying degrees adapted in the process, not least by early career researchers (e.g. Sengers, 2016; Ghosh and Schot, 2019). Such work is important and valuable but also ultimately revisionist rather than starting from non-Western modes of thinking and/or a more explicit inductive approach. Deeper and fuller engagement with postand decolonial ${ }^{1}$ thought across the social sciences and humanities has much to offer to STR. This can help to circumvent situations where the logics and potential explanations of core STR theories do not fit empirical realities in particular places (see Korsnes, 2020) and reduce the risk that relevant elements and processes in those places are rendered invisible because they are incommensurate with those theories. STR can generate pertinent insights into service provision to informal settlements (van Welie et al., 2019), but our ongoing research suggests that important elements of frugal innovation processes in such settlements are beyond the purview of core theories. More generally, STR has so far had little to say about how transition trajectories are conditioned by coloniality, the ongoing legacy of colonialism after countries have de jure become independent (Quijano, 2000).

Starting STR from a position of deep immersion in post/decolonial theories has a second set of benefits, for it will help STR to recognise the historical and geographical situatedness and specificity of concepts, logics and explanations more fully. It reinforces the need for humility in its onto-epistemological claims and methodological practices and highlights the need to 'learn to unlearn' (Lawhon et al., 2016) already familiar concepts, categories and theorymaking practices. After all, one insight emerging from decolonial theories is that western colonialism and the belief in universally applicable theories and concepts of social reality have historically co-evolved (e.g. Mignolo, 2011). A solution may be to provincialise transition theories by relocating theory-making to 'ex-centric sites' (Bhabha, 1994; Comaroff and Comaroff, 2012) and theorise there in strongly place-centric, bottom-up ways.

\section{Conclusions}

STR has grown, morphed and transitioned from a niche perspective on the outskirts of sustainability scholarship to its centre-stage. 'Founding' theoretical frameworks have been essential to this trajectory and will remain crucial for its future. We too will keep using them in our own research and teaching. Yet, if transition scholars are to respond to pressing contemporary challenges and aim to ensure that change happens sustainably, not just in Europe, but around the world, then they should also welcome the theoretical pluralisation advocated here, which may help to develop a critical sustainability transitions studies which adopts alternative roles, responsibilities and practises for scholars.

\footnotetext{
${ }^{1}$ The 'pre'/'post' distinction matters (see Mignolo, 2011; Bhambra, 2014).
} 


\section{References}

Avelino, F., Grin, J., Pel, B. and Jhagroe, S. (2016). The politics of sustainability transitions. Journal of Environmental Policy \& Planning 18(5): 557-567.

Bhabha, H.K. (1994). The Location of Culture. Routledge, New York.

Bhambra, G.K. (2014). Postcolonial and decolonial dialogues, Postcolonial Studies, 17:2, $115-121$.

Bussolini, J. (2010). What is a dispositive? Foucault Studies, 10, 85-107 DOI: https://doi.org/10.22439/fs.v0i10.3120

Korsnes, M (2020) Wind and Solar Energy Transition in China, Routledge, Abingdon.

Feola, G. (2019). Capitalism in sustainability transitions research: time for a critical turn? Environmental Innovation and Societal Transitions.

DOI:10.1016/j.eist.2019.02.005

Ford, R., Walton, S., Stephenson, J., Rees, D., Scott, M., King, G., Williams, J. and Wooliscroft, B. (2017). Emerging energy transitions: PV uptake beyond subsidies, Technological Forecasting and Social Change, 117, 138-150.

Ghosh, B. and Schot, J. (2019). Towards a novel regime change framework: Studying mobility transitions in public transport regimes in an Indian megacity, Energy Research and Social Science, 51, 82-95.

The Guardian (2019). Guardian Polluters Series. Available at: https://www.theguardian.com/environment/series/the-polluters

Köhler, J., Geels, F.W, Kern, F., Markard, J., Wieczorek, A., Alkemade, F., Avelino, F., Bergek, A., Boons, F., Fünfschilling, L., Hess, D., Holtz, G., Hyysalo, S., Jenkins, K., Kivimaa, P., Martiskainen, M., McMeekin, A., Mühlemeier, M.S, Nykvist, B., Onsongo, E., Pel, B., Raven, R., Rohracher, H., Sanden, B., Schot, J., Sovacool, B., Turnheim, B., Welch, D. and Wells, P. (2019) An agenda for sustainability transitions research: state of the art and future directions. Environmental Innovation and Societal Transitions 31, 1-32.

Korsnes, M. (2020). Wind and Solar Energy Transition in China, Routledge, Abingdon.

Kuhn, T.S. (1962). The Structure of Scientific Revolutions. The University of Chicago Press, Chicago, IL.Lawhon, M., Silver, J., Ernstson, H. and Pierce, J. (2016). Unlearning (un)located ideas in the provincialization of urban theory. Regional Studies 50(9): 1611-1622.

Lawhon, M., Silver, J., Ernstson, H. and Pierce, J. (2016). Unlearning (Un)located ideas in the provincialization of urban theory, regional studies, 50:9, 1611-1622.

Markard, J., Raven, R., and Truffer, B. (2012). Sustainability transitions: An emerging field of research and its prospects, Research Policy, 41:6, 955-967.

Mignolo, W.D. (2011). The Darker Side of Western Modernity: Global Futures, Decolonial Options. Duke University Press, Durham, NC.

Quijano, A. (2000). Coloniality of power and eurocentrism in Latin America. International Sociology, 15:2, 215-232.

Rauschmayer, F., Bauer, T. and Schäpe, N. (2015). Towards a thick understanding of sustainability transitions - Linking transition management, capabilities and social practices, Ecological Economics, 109, 211-221. 
Schwanen, T. (2018). Thinking complex interconnections: transition, nexus and geography. Transactions of the Institute of British Geographers 43: 2, 262-283.

Sengers, F. (2016). Transforming transport in Thailand: experimenting for transitions in sustainable urban mobility, Technische Universiteit Eindhoven, Eindhoven. Available at: https://pure.tue.nl/ws/portalfiles/portal/14842699/20160218_Sengers.pdf

Smith, A. and Raven, R. (2012). What is protective space? Reconsidering niches in transitions to sustainability, Research Policy, 41:6, 1025-1036.

Stirling, A. (2011). Pluralising progress: From integrative transitions to transformative diversity, Environmental Innovation and Societal Transitions, 1:1, 82-88.

Van Welie, M.J., Truffer, B. and Gebauer, H. (2019). Innovation challenges of utilities in informal settlements: Combining a capabilities and regime perspective, Environmental Innovation and Societal Transitions, 33, 84-101.

Zolfagharian, M., Walrave, B., Raven, R. and Romme, A.G.L. (2019). Studying transitions: Past, present, and future. Research Policy 48, 103788. DOI:

https://doi.org/10.1016/j.respol.2019.04.012 